\title{
Cultivation of College Students' Library Consciousness As Well As Reform and Revolution of Library Administration in Colleges and Universities
}

\author{
Xia Ou yang ${ }^{1, a}$, Jiaming Zhong ${ }^{1, b}$ and Naizhu Huang ${ }^{1, c^{*}}$ \\ ${ }^{1}$ Xiangnan University, Chengzhou, Hunan, China \\ aoyxcngg@163.com, bjmzhongcn@163.com, chuangnzh@163.com \\ ${ }^{*}$ corresponding author
}

Keywords: College and university students; Library consciousness; Higher institutions

\begin{abstract}
Library consciousness means personal or social attitudes and values toward libraries. One's library consciousness can be seen as an especially important standard for inquiry study as well as future creative work. In order to improve educational quality in higher institutions, colleges and universities should vigorously cultivate college students' library consciousness; while libraries in colleges and universities should have creations in administrative ideas, services and systems.
\end{abstract}

\section{Introduction}

Educational quality is vitally important for higher institutions' survival, so it is an eternal theme for higher institutions to improve educational quality. With the transition of elite education to massive education, the quality of students have been greatly different with lack of educational resources, which has brought serious challenges for schools' educational management, educational reform as well as their sustainable development. According to English scholar, Peter Scott, with the expansion of enrollment as well as education popularity, educational quality has become an extremely important factor for higher institutions' development, and it has also become a hottest issue among all walks of life. Therefore, the State Ministry of Education has issued the Number 4 document "Several Opinions on Improving Higher Education Quality Comprehensively by Ministry of Education". It advocates that talent cultivation should be seen as the center of higher education by setting scientific development view and insisting a development mode with stable scale, optimized structure, strong features and great innovations, so as to improve the quality and connotation. In order to carry out the spirits in Number 4 document and promote higher education quality, libraries play an important role. Zhou Guoping, a famous philosopher, pays much attention to the role of libraries. According to him, there are great books from all over the world in libraries, but students spend time working on the tedious textbooks. Although his words are extreme, they arouse our reflections on education. What can libraries do to improve the quality of higher education? How should libraries formulate an administrative system suitable for students and teachers' development surrounding the concept of teaching-oriented education.

\section{Cultivation of Library Consciousness and Students' Library Consciousness}

Library is an institutions of great book collections in colleges and universities where students can borrow books, refer to materials and conduct researches. According to United States Science Foundation(which is short for USSF) and Keith Institute, during scientific researches, the time of writing reports and papers only accounts for $9.3 \%$ of the total research time, the time of panning and experiment accounts for $39.8 \%$, while the time of referring to materials accounts for $50.9 \%$. Besides, more time is needed to refer to literature during social and scientific researches. However, it's a pity that contemporary college students haven't realized the position and function of libraries without a universe library consciousness. What is library consciousness? Its main essence is that personal or social attitudes and values toward libraries. While as for library administrators, it means their strong service consciousness and self-responsibility consciousness for readers. Their 
responsibility is to give a maximum play to library functions. As for teachers and students, library consciousness means awareness of conduct researches and studies. In other word, whether a person has library consciousness or not can be seen as an important standard to judge if he or she has ability of conducting inquiry study and creation. Thus, during the process of higher education, students and teachers' library consciousness should be promoted, so they can understand that in today's information age, one's success relies on his or her capability of discovering, accessing, analyzing and summarizing information and knowledge as well as capability of combing information and knowledge with personal career development. In the information age, the relationship between students and teachers are a research partner relationship, during which students manage to obtain knowledge through information searching, reading, analyzing and summarizing with methods offered in class. Students try to find information and knowledge what they want by library searching tools. That is, students' learning process is actually a process teachers instruct students to develop course resources and to conduct cooperative exploration; and it is also a process teachers lead students to confirm, evaluate, search and use information with the help of library. During the establishment of modern university system, the functions of library will be reformed inevitably, which will lead to a series of educational and teaching reforms. The learning focus of students will transfer from class to library, and teachers' responsibilities will transfer from teaching and answering to concerning about students' abilities of independent study as well as referring to related literature. Meanwhile, the main point of teachers' work will also change from class to library to make library a lively classroom as well as a base for cultivating students' library consciousness. However, cultivation of library consciousness also relies on the reform of education, during which the traditional instilling education should be changed into inquiry education widely. Besides, teachers themselves should also possess sound library consciousness because it is vitally important to cultivate students' library consciousness. Responsibilities of teachers in the $21^{\text {st }}$ century are encouraging students to think more instead of teaching knowledge only. Apart from some official functions, teachers are becoming a counselor as well as a participant since they help students to find contradictory opinions rather than tell them truths directly. Teachers should spend more time and energy on those effective and creative activities such as interactive influence, discussion, encouragement, understanding and excitation. As a college student with creative consciousness, creative spirit and creative abilities, he or she must be a person with modern library consciousness since creation is not only inheritance and development of existed culture, but it also carries forward former researches, which all relies on the functions of library. Higher institutions are in urgent need of library consciousness, so they don't merely want to arouse library administrators' awareness of service, responsibility, profession and devotion, but they also want a revolution in education and educational concepts so as to break through the old-dated library concepts and stereotyped thinking modes. Thus each one can realize that library is not merely a place with great book collections, but is is also a heaven for study, a good place for creation, a sky for mind wandering as well as a beautiful place for communication with masters.

\section{Main Problems Existing in Library Administration in Higher Institutions}

In order to cultivate college students' library consciousness, both educational concepts and educational administration need to be deeply reformed as well as revolution of library administration system. Although libraries have made great contribution to improving educational quality during higher education popularity, the potentials haven't been fully explored yet without giving full play to current effect. What's worse, the invisible functions on educating people, cultivating people and developing people can't be valued. The reason is that library administrators only treat themselves as mangers instead of people who offer service to students. The library is seen as an institute of book collections. In addition, our school education is lack of complete mechanism leading students to libraries, so teachers do not set good examples for students. That is to say, the whole school is lack of a strong consciousness encouraging students to read books in libraries.

The Position of Library Is Lack of Enough Attention. Library is one of the three pillars of higher institute, which plays an important role in improving higher education, scientific research as 
well as educational quality; however, the strategic role of library hasn't reached enough knowledge and importance in reality. Most higher institutes regard library as a place for unqualified personnel, leading to a generally poor quality of library personnel without many professional and high-end talents in computer science. Such kind of personnel structure will not only affect working efficiency, but it can also impede the generation of creative ideas. Meanwhile, the staff won't have the resolution to take library as their lifelong career. Thus, it is in urgent need to enlarge the personnel of professional talents for a better library work.

The Libraries Are Short of Collections with an Irrational Structure of Professional Books. The quantity and structure of a library is a hard indicator to measure a library's functions, which manifests in amounts and yearly new books for the evaluation of educational quality. The total amount of collections should reach 80 books per student, and yearly new books should meet 4 books per student. For example, if a university has 20,000 students, its library collections should be 1.6 million and the yearly new books should be 80,000 . If each book costs 30 yuan, then at least 2.5 million yuan is wanted for purchasing books. In fact, some universities in undeveloped areas can't afford so much money. Due to limited expenditure as well as purchaser's qualities, many books' quality can be ensured, and professional books and intelligence information cover fewer fields. What's worse, new books can't be registered and verified timely, which all lead to an increasingly prominent contradiction between libraries and teaching research.

The Administration Mode of Library Is Lack Behind Social Demand. The administrative mode of a library means the service way that a library adopts. That is, whether the library mainly offers circulation service or reading service, and whether the service is open to students or closed to students. At present, the administrative modes of libraries are traditional mode, transitional mode and modern mode. The so-called traditional mode specially means that the services of collection, lending, reading and administration are separated, and its archaeological function is relatively stable. The modern mode means a large space without any special interaction where services of collection, lending, reading and administration are all unified. Such kind of library archaeology can undertake unified service of books and intelligence information. While transitional mode is half of the two kinds above. Libraries in higher institutions mainly serve college students and teachers who need large quantity of professional information, so they need more reading to acquire resources freely. Thus libraries should change the traditional administrative mode based on collection; instead they should include more useful resources for readers' need, and meanwhile allocate talents and resources rational and effectively so as to achieve scientific management and usage. Nowadays, the unified collection-reading mode is widely used in higher institutions' libraries. Compared to previous mode, it can give readers larger and wider space for reading with more reading freedom. Readers won't feel inconvenient due to backward searching means and deficient knowledge background of library managers.

The Quality of Service in Libraries Needs to Be Promoted Urgently. Due to the popularity of modern office equipment, usage of automatic books management system and digitization of collected resources, contemporary libraries have become increasingly modern. But compared to readers' increasing demand for literature, service means in libraries as well as the service contents are really shallow. Generally they offer service passively without any personalized and active service. Let alone meet the goal of "think what readers think and concern what readers concern". Besides, the promotion of libraries should be strengthened, such as introduction of library functions, book collections, recommendation of major books as well as asking for lent books. In addition, with the constant enrollment of students, the amount of readers is becoming larger and larger, which leads to fight among students for spared seats. Therefore, while formulating administrative system and solving contradicts, library managers should put themselves into students' shoes to make each reader satisfied.

An Excitation Scheme Is Wanted for Library Administration. The contemporary libraries are lack of creativity and excitation scheme. During their work, experience is more important than creativity. Thus, administrators have low activeness, poor sense of responsibility and poor quality. Besides, library managers are passive with talents drains due to low salary and poor welfare. 


\section{Reflections on the Creation of Library Administration System in Higher Institutions}

According to some American library administrators, among all functions of libraries, the archaeology accounts for $5 \%$, information materials account for $20 \%$, while administrative staff account for $75 \%$. Therefore, in order to explore the potentials of libraries, we can manage to reform the library administration system as well as improve the quality of service since the library archaeology can't be changed thoroughly.

Innovation of Administrative Concepts for Libraries in Higher Institutions. Innovation of concept is the precondition of all administrative activities. Whether the library has advanced concept will restrict the administrative effect directly. Thus, administrators of libraries in higher institutions should set creative consciousness and dare break through old regulations and traditional concepts. They should formulate scientific strategies for development and administration according to social and economic development and the quality of higher education.

(1)People-oriented concept: People-oriented concept is a basic opinion of Marxism, including two basic means. First, it emphasizes the values of human instead of stuff with emphasis on human's creativity and personality. Second, it refers to massive people instead of ruling class. As for library management in higher institutions, it contains two aspects. That is, the service objects of students and teachers and the service subject of library managers. To implement people-oriented concept requires managers to publicize humanity, emphasize human's subjective role, respect human's values and dignity and conduct all work surrounding people with human as the center. All decisions and regulations should be in accordance with humanity, which can not only educate people, lead people, encourage people and stimulate people, but also respect people, understand people, care about people, help people and develop people. The purpose is to satisfy people's demands and stimulate people's creative potentials by respecting humanity, and thus give play to people's values to maximum extent. In this way, the administrative goals and achievements can be reached and promoted.

(2) The scientific administrative concept: Talent is the precondition for conducting activities and completing tasks successfully with high quality. In order to fully explore the potentials of current libraries, the important precondition is to set scientific administrative concept. With the constant development of computer network technology, library managers have to formulate new policies for talent introduction advent of library digitization and informatization by vigorously introduce high-end talents of library and computer majors rather than regard libraries as places for spared personnel, and thus they can adapt themselves to the development of digitization. Meanwhile, the introduced talents should be assigned to particular positions by scientific administration principle so as to reach a rational allocation. First, the working process in libraries should be set scientifically with rational arrangement of positions and simplified working sections so that literature information service system can be practical and convenient. Second, proper staff should be arranged for different positions. Managers with special strengths and different capabilities should be arranged for different library jobs with scientific and rational arrangement. Library administrators can do suitable jobs by their capabilities, levels of knowledge and specialties. Third, a free, easy and a sound working environment should be created for each library administrator.

Innovation of Administration and Services in Libraries of Higher Institutions. (1) Innovation of service contents: The service effect of a library is mainly determined by its service contents. The most basic services of a library are to collect, store, organize and communicate literature information, and its main responsibilities is to ensure the openness of library to teachers and students unconditionally and comprehensively. Therefore, libraries should actively listen to teachers and students' opinions by carrying out different kinds of talks to know about their reading status timely, which can provide guidance for library development and define the orientation of deepening services. In addition, libraries should also pay attention to special services. For example, they should introduce and establish special database based on the school features and collection systems by establishing information navigation and readers' navigation system for major subjects and majors so as to strengthen the coordination and cooperation among different libraries, achieving a real resource sharing. Besides, while sorting various literature resource, libraries should establish 
a group of database with strong specialty so as to timely track and master the latest research results and dynamic development of science and research. Meanwhile, services of recommendation and navigation should be set for new masterpiece to enlarge the service contents of literature materials.

(2)Innovation of service means: The service objects of libraries in higher institutions are teachers and students who are up to science and research. The special quality of service objects requires a comprehensive and open service from libraries. That is, the library should be open to all students and teachers all day long by offering diversified services such as establishment of consultant department and propagation department and so on so that all students and teachers can refer to information conveniently and freely. As for the service means, the libraries should also offer some specific services to readers for information sorting, analysis and summary. They can also help to organize some science and research activities related to teachers and students such as academic meetings, reports and lectures. Besides, in order to improve the quality of service, the traditional mode and original collection layout should be changed into a collection-reading mode by making full use of reading rooms. All books can be placed by subjects. Apart from seed stack, all front-line books should be open to readers who can either read there or borrow books away.

(3)Innovation of service range: Innovation of service range means to conduct special services based on some basic services. Due to the lack of expenditures, the copy ratio and single books have increased with a high rate of anti-lending phenomenon. Thus, more reading rooms should be enlarged to increase the attraction of libraries to readers. In addition, apart from some basic services offered by libraries, they should also offer some creative service mode by enlarging their service range. The various services of libraries should be extended to communities, middle and primary schools and enterprises by making the best use of rich literature resources.

(4) Innovation of charged services: While offering some free services in schools, libraries should also carry out some charged services, which is not only beneficial to transit passive services into active service, but also can make the full use of current books and materials so as to promote the social and economic effect of libraries; and meanwhile the libraries can be developed better to solve some backward problems such as less collections, unstable personnel staff and poor service means. The charged services mainly manifest in offering special services to particular readers and social groups. For example, some qualified libraries can cooperate with enterprises and scientific institutes by establishing information development companies so that they can offer information consultancy and intelligence information analysis and service. Besides, they can also conduct some deepening charged services such as tracked services, translation, and literature copy and literature edition. Some small libraries with poor power can give out library card to public to implement charged lending. They can also undertake the copy business, journal binding, bookstore establishment and book purchasing and so on to acquire some income.

Innovation of Library Administration System in Higher Institutes. In the age of knowledge economy, in order to achieve a sound development in the fierce competition, libraries in higher institutes have to abandon backward administration system and to implement innovative administration system.

(1)Innovation of personnel management system: The knowledge economy is based on knowledge and intelligence, so talents, as the carrier of knowledge and intelligence, play an important role in developing knowledge economy. The competition among college libraries is actually the competition of management and service, and it is the competition among talents finally. During the traditional library personnel management, human hasn't been treated as an important resource, which leads to serious talents idle and depression with poor sense of responsibility, activeness, initiative and creation. Therefore, the personnel staff in college and university libraries should make some innovations by employing talents of comprehensive qualities with proper salary and positions. In this way, the personnel management system will rely on the staff's academic standard, working attitude and quality of service instead of experience or relations, which can truly form a sound personnel management system.

(2) Innovation of the appointment system for professional titles: Libraries in higher institutes carry out scientific and standard personnel management, which aims to mobilize the staff's working 
activeness. Within the allowance of programmed system, libraries can employ talents according to professional knowledge instead of experience and positions only so as to break through the concept of lifelong job.

(3) Innovation of rotational communication system: Due to the short period of knowledge update, new knowledge and new technologies arise continuously. So it is an effective way to promote the establishment of libraries by competition and rotation. For example, positions and qualifications can be publicized by adopting organizational recommendation and public recommendation. By this way, the traditional system can be changed. Besides, the rotation system is beneficial to know about the whole appearance of libraries in higher institutions and thus create a sound circumstance for study. The whole organization can be a new type of organization by absorbing new knowledge and creating new knowledge, which can help to cultivate new talents and strengthen the competitive.

\section{Acknowledgement}

This paper is sponsored by educational reform and research project for higher institutions in Hunan province. That is, Theories and Empirical Researches on the Transition and Development of Local Colleges and Universities by Taking Xiangnan University As an Example. (Hunan Education and Communication. No[2015]291); Educational and Scientific Planning Subject in Hunan province, which is Study on the Diversified Governance Model in Local Colleges and Universities Under the Comprehensive Educational Reform (XJK014BGD076); Educational Reform and Research Project in Xiangnan University (Analysis on the reform of extensive educational model based on independent reading).

\section{References}

[1] Anthony Smith, Frank Webster: The Postmodern UniverSity--Contest Visions of Higher Education in Society (Open University Press, Buckinggham 1997).

[2] Zhou Guoping: Cited from Discussion on Education (Press of East China Normal University, China 2009).

[3] X.P.Zhen: Journal of Hubei Normal University (Philosophical and Social Science Version), (1996) No.6.

[4] D.F.Hu: New Ideas of Education (Press of Guangxi Normal University, China 2003).p.37.

[5] United Nations Educational Scientific and Cultural Organization: Learn to Survive is the Today and Tomorrow of Education (Press of Education, China 1996), p.108.

[6] Book Intelligence Science (1B): Analysis on the Existing Problems and Reform Policies in Libraries of Higher Institutions, p.73. 